\title{
Intake, digestibility and rumen fermentation pattern in wethers fed total mixed ration silage containing dry or fresh apple pomace
}

\author{
G.-j. Xia ${ }^{1}$ and J.-c. Fang ${ }^{2,3}$ \\ ${ }^{1}$ Agricultural College of Yanbian University, Yanji 133002, Jilin Province, China \\ ${ }^{2}$ Hirosaki University, Faculty of Agriculture and Life Science, Hirosaki, Aomori, 0368561, Japan
}

KEY WORDS: apple pomace, digestibility, feed intake, rumen parameters, sheep, total mixed ration silage

Received: 16 November 2020

Revised: $\quad 3$ March 2021

Accepted: $\quad 7$ March 2021

${ }^{3}$ Corresponding author:

e-mail: fang@hirosaki-u.ac.jp

\begin{abstract}
The fermentation quality of total mixed ration silage (TMRS) prepared with dry apple pomace (DAP) or fresh apple pomace (FAP), as well as their effects on digestibility and rumen fermentation in feeding wethers were evaluated. Maize, wheat bran, soyabean meal, timothy and alfalfa hay were used to compose TMRS. Proportions of DAP and FAP in TMRS were $200 \mathrm{~g} / \mathrm{kg}$ dry matter (DM) each, and the moisture content of TMRS was adjusted to $550 \mathrm{~g} / \mathrm{kg}$ and ensiled for 60 days. The mixture of TMR with DAP without ensiling was used as a control diet, and experimental treatments were TMRS with DAP and TMRS with FAP. The TMRS with DAP and FAP were well fermented, with low $\mathrm{pH}$ and high lactic acid content. Ethanol was produced in both TMRS treatments and was significantly higher in that with FAP. Nitrogen retention and digestibility of DM, organic matter and crude protein were significantly lower in the treatments with DAP and FAP than in control one. Four hours after feeding TMRS with DAP and FAP, the rumen molar proportion of acetic acid was higher, while those of propionic acid and ammonia nitrogen content were lower, with more pronounced changes in the treatment with FAP. The results of this study suggest that the proportion of DAP or FAP in TMRS should not exceed $200 \mathrm{~g} / \mathrm{kg}$ of diet DM.
\end{abstract}

\section{Introduction}

Apple pomace is a by-product that remains after milling and pressing apples for juice and cider production. It is usually a seasonal product available after the autumn harvest and is produced in large amounts in many countries (Perussello et al., 2017). Apple pomace has many uses, such as for food, pectin, citric acid and dietary fibre production (Shalini and Gupta, 2010). Demand for it as feed is expected to increase with a global supply shortage of feed grains and rising feed prices. As a feed material, the chemical composition of fresh apple pomace (FAP) is characterized by high moisture and fermentable sugar contents and low crude protein (CP) content (Gasa et al., 1992). It was shown that FAP promotes silage fermentation (Fang et al., 2016). However, it was also indicated that silage containing FAP produces not only organic acids but also ethanol. Ethanol contains high energy and volatilizes easily, however when its content in silage is high, a loss of energy and dry matter (DM) may occur through volatilization (Pedroso et al., 2005). Furthermore, in some studies it was observed that ethanol affects cow milk composition and flavour (Randby et al., 1999) and reduces feed digestibility in ruminants (Emery et al., 1959; Fang et al., 2016). Because of high moisture content, FAP is challenging to transport over long distances, limiting its widespread use. In practice, apple pomace as feed material is circulated in a dry state. Because most of the circulated dry apple pomace (DAP) 
has been dried at temperatures of more than $100^{\circ} \mathrm{C}$, the microorganisms attached to the apple pomace that affect fermentation, such as lactic acid bacteria and yeast, may decrease or die out. Consequently, this may result in different fermentation patterns for total mixed ration silage (TMRS) containing DAP or FAP, particularly regarding ethanol production. Although ethanol production via fermentation of DAP under industrial conditions has been widely evaluated (Magyar et al., 2016), its effects on feed silage fermentation are not fully estimated. So, fermentation characteristics, particularly ethanol production of total TMRS prepared with either DAP or FAP were evaluated in the present study. Feed intake, digestibility, nitrogen $(\mathrm{N})$ retention and rumen fermentation were also estimated in wethers to determine which form (dry or fresh) of apple pomace is more beneficial for ruminants.

\section{Material and methods}

\section{TMRS preparation}

Apple pomace was obtained from a commercial juice factory (Aoren, Aomori, Japan), and FAP was used to prepare TMRS immediately after production. The DAP needed for the experiment was prepared in a commercial factory (Nihon-Kouken, Aomori, Japan), where it was dried with hot air at $110{ }^{\circ} \mathrm{C}$ while being stirred for $4 \mathrm{~h}$. Experimental diets were prepared with FAP or DAP together with TMRS with maize, wheat bran, soyabean meal, timothy hay, alfalfa hay and a vitamin-mineral supplement (Snow Brand Seed, Sapporo, Japan). The moisture content of DAP was adjusted to be equal to the calculated value of FAP treatment $(550 \mathrm{~g} / \mathrm{kg})$. The proportion of DAP or FAP in the TMRS was $200 \mathrm{~g} / \mathrm{kg}$ DM; CP content and proportion of roughage were determined according to Xu et al. (2008). The mixture of TMRS material with DAP without ensiling was used as a control diet. When preparing the TMRS, timothy and alfalfa hay were cut into $2-\mathrm{cm}$ pieces. All materials were well stirred using a heavy mixer, and the moisture content of DAP was adjusted by gradually adding water. Overall, $300 \mathrm{~kg}$ of TMRS with FAP and DAP were prepared and ensiled equally into three 200-1 sealing-type drum silos (Maeda Manufacturing Co. Ltd., Ichihara, Japan) after being fully compressed. Then the TMRS was stored outdoors $\left(4.4-25.8^{\circ} \mathrm{C}\right)$ to ferment for 60 days.

\section{Animals and feeding trial}

The experiment was approved by the committee of animal experimentation and performed under the institutional guidelines for animal experiments of Hirosaki University (Japan). Four Suffolk wethers (body weight $=65.3 \pm 3.4 \mathrm{~kg}$ ) were used for the experiment and were fed control, DAP and FAP diets in three separate experiments. The wethers were housed individually in metabolic cages $(150 \times 60 \times$ $100 \mathrm{~cm}$, with a function of collecting faeces and urine separately) and fed diet ad libitum to ensure $10 \%$ residual. The moisture content of control diet was also adjusted to $550 \mathrm{~g} / \mathrm{kg}$ just before feeding to ensure consistent texture and mouthfeel with the TMRS.

The diets were fed in two halves at 07:00 and 19:00, and refusals were weighed before the morning feedings. The wethers had free access to water and mineral blocks during the experiments. Each experiment lasted 21 days, including a 14-day adaptation period followed by a 7-day faecaluria collection period. During each collection period, samples of faeces were collected twice a day, in the morning and afternoon, urine was also collected into a bottle containing $0.3 \mathrm{ml}$ hydrochloric acid $(100 \mathrm{mg} / \mathrm{g})$, then $3 \%$ of the faeces and urine by weight was stored at $-20{ }^{\circ} \mathrm{C}$.

At the end of each period, the stored faeces and urine were combined and mixed fully, and then a sample was collected for chemical analyses. Rumen fluid was collected using a rumen catheter (Sanshin Industrial, Yokohama, Japan) at $0^{\text {th }}$ (before feeding) and $4^{\text {th }} \mathrm{h}$ after feeding on the last day of each period. Rumen fluid $\mathrm{pH}$ was measured immediately, and samples were separated from feed particles by filtration through four layers of gauze followed by centrifugation at $1200 \mathrm{~g}$ for $15 \mathrm{~min}$ at $4{ }^{\circ} \mathrm{C}$. The sample fluid was stored frozen $\left(-20^{\circ} \mathrm{C}\right)$ for further analyses of volatile fatty acid (VFA) and ammonia $\mathrm{N}$.

\section{Sampling and chemical analysis}

Samples of TMRS for chemical analyses and fermentation quality were taken equally from the upper, middle and lower parts of each drum silo, combined and mixed fully. The moisture content of the TMRS was measured using the toluene distillation method according to Dewar and McDonald (1961). Diet and faeces samples were dried in a forced-air oven at $60{ }^{\circ} \mathrm{C}$ for $48 \mathrm{~h}$ and ground to pass a $1-\mathrm{mm}$ screen with a sample mill. Dry matter, CP, ether extract (EE) and ash were analyzed according to AOAC (1990) methods 934.01, 976.05, 920.39 and 942.05, respectively. Urinary $\mathrm{N}$ was determined using the Kjeldahl procedure (AOAC, 1990). The neutral detergent fibre (NDF) and acid detergent fibre (ADF) were determined following the methods of Van Soest et al. (1991) with amylase and sodium sulphite; 
the presented results include residual ash. Gross energy (GE) was determined using an automatic bomb calorimeter (CA-4PJ, Shimadzu Co. Ltd., Kyoto, Japan). The TMRS fermentation products were determined from the liquid extract. Wet samples $(100 \mathrm{~g})$ were homogenized with $300 \mathrm{ml}$ sterilized distilled water for $5 \mathrm{~min}$ using a mixer, then filtered through four gauze layers (Cai et al., 1999). Filtrate $\mathrm{pH}$ was measured using a glass electrode $\mathrm{pH}$ meter (D-21; Horiba Co. Ltd., Tokyo, Japan). Lactic acid and ammonia $\mathrm{N}$ were determined according to Barker and Summerson (1941). The VFA was steam-distilled and measured qualitatively and quantitatively by gas chromatography (G-5000A; Hitachi Co. Ltd., Tokyo, Japan). The ethanol content of the TMRS was determined using the gasification balance method according to Xu et al. (2001). The VFA and ammonia N contents of rumen fluid were measured using the same methods as for TMRS filtrates.

\section{Statistical analysis}

The data of fermentation products of the two TMRS were analyzed using the independent t-test. Data of chemical composition, nutrient digestibility, $\mathrm{N}$ retention and rumen fermentation of three treatments were analyzed using one-way ANOVA. Statistical comparisons were made using TukeyKramer tests. Differences were considered significant at a threshold of $P<0.05$. Statistical analyses were performed using SPSS software ver. 25 (SAS Institute Inc., Cary, NC, USA).

\section{Results}

\section{Chemical composition of materials and TMRS}

Very low DM and CP contents of 151 and $76.1 \mathrm{~g} / \mathrm{kg} \mathrm{DM}$, respectively were noted in FAP (Table 1). Almost no differences in chemical composition between DAP and FAP were observed, and their NDF content was close to that of alfalfa hay, which is a very good quality feed for ruminant nutrition. Since ingredient proportions of TMRS were almost identical except for the apple pomace, the three diets had similar chemical compositions (Table 2).

\section{Fermentation quality of TMRS}

Low $\mathrm{pH}$ and high lactic acid contents were found in TMRS with DAP and FAP (Table 3), ethanol was generated in both DAP and FAP treatments but was significantly higher in FAP one $(P<0.05)$. Conversely, the lactic acid, acetic acid
Table 1. Chemical composition of materials used in the experiment

\begin{tabular}{|c|c|c|c|c|c|c|c|}
\hline $\begin{array}{l}\text { Indices, } \\
\text { g/kg DM }\end{array}$ & DAP & FAP & $\begin{array}{l}\text { Soyabean } \\
\text { meal }\end{array}$ & Maize & $\begin{array}{l}\text { Wheat } \\
\text { bran }\end{array}$ & $\begin{array}{l}\text { Timothy } \\
\text { hay }\end{array}$ & $\begin{array}{l}\text { Alfalfa } \\
\text { hay }\end{array}$ \\
\hline $\mathrm{DM}, \mathrm{g} / \mathrm{kg}$ & 924.8 & 151.0 & 868.8 & 855.1 & 862.3 & 874.3 & 875.7 \\
\hline $\begin{array}{l}\text { Organic } \\
\text { matter }\end{array}$ & 964.1 & 963.9 & 931.1 & 987.0 & 942.2 & 935.0 & 896.5 \\
\hline $\begin{array}{l}\text { Crude } \\
\text { protein }\end{array}$ & 75.9 & 76.1 & 484.0 & 81.3 & 178.7 & 105.2 & 216.7 \\
\hline $\begin{array}{l}\text { Ether } \\
\text { extract }\end{array}$ & 59.6 & 60.0 & 15.2 & 4.8 & 46.9 & 9.3 & 14.7 \\
\hline $\begin{array}{l}\text { Acid } \\
\text { detergent } \\
\text { fibre }\end{array}$ & 344.8 & 342.2 & 90.2 & 32.7 & 141.3 & 383.4 & 312.2 \\
\hline $\begin{array}{l}\text { Neutral } \\
\text { detergent } \\
\text { fibre }\end{array}$ & 431.1 & 428.9 & 148.1 & 123.2 & 463.1 & 641.7 & 441.8 \\
\hline Ash & 35.9 & 36.1 & 68.9 & 13.0 & 57.8 & 65.0 & 103.5 \\
\hline
\end{tabular}

Table 2. Ingredient proportions and chemical composition of the experimental diets

\begin{tabular}{|c|c|c|c|c|c|}
\hline Indices & Control & FAP & DAP & SEM & $P$-value \\
\hline \multicolumn{6}{|l|}{ Ingredient, g/kg DM } \\
\hline fresh apple pomace & - & 200 & - & - & - \\
\hline dry apple pomace & 200 & - & 200 & - & - \\
\hline soyabean meal & 78 & 78 & 78 & - & - \\
\hline maize & 132 & 132 & 132 & - & - \\
\hline wheat bran & 93 & 93 & 93 & - & - \\
\hline timothy hay & 243 & 243 & 243 & - & - \\
\hline alfalfa hay & 240 & 240 & 240 & - & - \\
\hline $\begin{array}{l}\text { vitamin-mineral } \\
\text { supplement }\end{array}$ & 14 & 14 & 14 & - & - \\
\hline \multicolumn{6}{|c|}{ Chemical composition, g/kg DM } \\
\hline DM, g/kg & 449.1 & 444.7 & 446.7 & 1.27 & 0.593 \\
\hline organic matter & 940.9 & 936.2 & 939.4 & 1.39 & 0.182 \\
\hline crude protein & 162.8 & 161.2 & 159.2 & 1.04 & 0.395 \\
\hline ether extract & 29.8 & 28.1 & 30.7 & 0.76 & 0.457 \\
\hline acid detergent fibre & 260.3 & 258.8 & 259.7 & 0.44 & 0.991 \\
\hline neutral detergent fibre & 439.7 & 442.5 & 431.2 & 3.40 & 0.573 \\
\hline gross energy, MJ/kg DM & 19.0 & 18.9 & 18.9 & 0.03 & 0.971 \\
\hline
\end{tabular}

DM - dry matter, Control - DAP treatment without ensiling, FAP - treatment as total mixed ration silage containing fresh apple pomace, DAP - treatment as total mixed ration silage containing dry apple pomace, SEM - standard error of the mean

Table 3. Fermentation quality of total mixed ration silages $(n=3)$

\begin{tabular}{lccrr}
\hline Indices & DAP & FAP & SEM & $P$-value \\
\hline pH & $3.98^{\mathrm{b}}$ & $4.11^{\mathrm{a}}$ & 0.06 & 0.022 \\
Ethanol, g/kg FM & $8.93^{\mathrm{b}}$ & $36.1^{\mathrm{a}}$ & 13.59 & $<0.001$ \\
Lactic acid, g/kg FM & $19.2^{\mathrm{a}}$ & $17.6^{\mathrm{b}}$ & 0.80 & 0.023 \\
Acetic acid, g/kg FM & $10.4^{\mathrm{a}}$ & $6.8^{\mathrm{b}}$ & 1.82 & $<0.001$ \\
Propionic acid, g/kg FM & $\mathrm{ND}$ & $\mathrm{ND}$ & - & - \\
Butyric acid, g/kg FM & $\mathrm{ND}$ & $\mathrm{ND}$ & - & - \\
Ammonia nitrogen, g/kg TN & $18.0^{\mathrm{a}}$ & $16.6^{\mathrm{b}}$ & 0.70 & 0.016
\end{tabular}

DAP - treatment as total mixed ration silage containing dry apple pomace, FAP - treatment as total mixed ration silage containing fresh apple pomace, SEM - standard error of the mean, FM - fresh matter, $\mathrm{ND}$ - not detected, TN - total nitrogen; ab - values within the same row with different superscripts are significantly different at $P<0.05$ 
and ammonia $\mathrm{N}$ contents were higher in the DAP treatment $(P<0.05)$. Neither propionic nor butyric acid were detected.

\section{Feed intake and digestibility}

The feed intake of DM was not affected by diet treatment $(P>0.05)$ (Table 4). Digestibilities of DM, organic matter, CP and GE were similar in DAP and FAP treatments but lower than that of the control treatment $(P<0.05)$. Digestibility of EE, ADF and NDF were the highest in the control treatment, followed by the DAP and FAP treatments $(P<0.05)$. No differences were found in $\mathrm{N}$ intake or urinary $\mathrm{N}$ among the treatments $(P>0.05)$, but faecal $\mathrm{N}$ was higher in DAP and FAP treatments, while retained $\mathrm{N}$ was higher in the control treatment $(P<0.05)$.

Table 4. Feed intake, nutrient digestibility and nitrogen balance in wethers fed experimental diets $(n=4)$

\begin{tabular}{|c|c|c|c|c|c|}
\hline Indices & Control & DAP & FAP & SEM & $P$-value \\
\hline $\begin{array}{l}\text { Feed intake, dry matter } \\
\text { g/day }\end{array}$ & 1211.6 & 1208.0 & 1210.5 & 1.07 & 0.753 \\
\hline \multicolumn{6}{|l|}{ Digestibility, \% } \\
\hline dry matter & $73.8^{\mathrm{a}}$ & $71.5^{b}$ & $70.4^{b}$ & 1.00 & 0.036 \\
\hline organic matter & $73.3^{\mathrm{a}}$ & $70.6^{b}$ & $70.4^{b}$ & 0.94 & 0.028 \\
\hline crude protein & $77.2^{\mathrm{a}}$ & $73.7^{\mathrm{b}}$ & $73.6^{\mathrm{b}}$ & 1.18 & 0.033 \\
\hline ether extract & $76.5^{\mathrm{a}}$ & $71.9^{b}$ & $61.2^{\mathrm{c}}$ & 4.53 & $<0.001$ \\
\hline acid detergent fibre & $61.3^{\mathrm{a}}$ & $59.2^{b}$ & $44.8^{c}$ & 5.92 & $<0.001$ \\
\hline neutral detergent fibre & $63.9^{a}$ & $60.7^{\mathrm{b}}$ & $50.7^{c}$ & 3.98 & $<0.001$ \\
\hline gross energy & $72.6^{\mathrm{a}}$ & $70.4^{b}$ & $70.1^{\mathrm{b}}$ & 0.78 & 0.034 \\
\hline \multicolumn{6}{|l|}{ Nitrogen retention, g/day } \\
\hline nitrogen intake & 31.6 & 30.8 & 31.2 & 0.23 & 0.531 \\
\hline urinary excretion & 16.3 & 15.8 & 16.2 & 0.15 & 0.655 \\
\hline faecal excretion & $7.2^{b}$ & $8.1^{\mathrm{a}}$ & $8.2^{\mathrm{a}}$ & 0.32 & 0.029 \\
\hline nitrogen retention & $8.1^{\mathrm{a}}$ & $6.9^{b}$ & $6.8^{b}$ & 0.42 & 0.008 \\
\hline
\end{tabular}

Control - DAP treatment without ensiling, DAP - treatment as total mixed ration silage containing dry apple pomace, FAP - treatment as total mixed ration silage containing fresh apple pomace, SEM - standard error of the mean; ${ }^{\text {abc }}$ - values within the same row with different superscripts are significantly different at $P<0.05$

\section{Rumen fermentation}

The diet treatment did not affect rumen $\mathrm{pH}$ or total VFA concentration at $0^{\text {th }}$ and $4^{\text {th }} \mathrm{h}$ after feeding $(P>0.05)$ (Table 5). Molar proportions of acetic and propionic acids, and the ratio of acetic acid to propionic acid (A:P) did not differ among the treatments $(P>0.05)$ at the $0^{\text {th }} \mathrm{h}$. However, the acetic acid molar proportion increased whereas that of propionic acid decreased in FAP and DAP in comparison to control treatment at the $4^{\text {th }} \mathrm{h}$ after feeding and differences were found among the treatments $(P<0.05)$. The A:P ratio has changed in accordance with significant differences among the treatments $(P<0.05)$. The diet treatments also affected molar proportions of butyric, valeric and caproic acids, and significant differences were observed at $0^{\text {th }}$ and $4^{\text {th }} \mathrm{h}$ after feeding $(P<0.05)$. The rumen ammonia $\mathrm{N}$ concentrations were similar for the three treatments at the $0^{\text {th }} \mathrm{h}(P>0.05)$.

Table 5. Rumen fermentation of wethers fed experimental diets $(n=4)$

\begin{tabular}{|c|c|c|c|c|c|}
\hline Indices & Control & DAP & FAP & SEM & $P$-value \\
\hline \multicolumn{6}{|l|}{$\overline{\mathrm{pH}}$} \\
\hline $0^{\text {th }} \mathrm{h}$ & 6.20 & 6.54 & 6.51 & 0.109 & 0.749 \\
\hline $4^{\text {th }} \mathrm{h}$ & 6.21 & 6.22 & 6.43 & 0.072 & 0.826 \\
\hline \multicolumn{6}{|c|}{ Total volatile fatty acid, mmol/l } \\
\hline $0^{\text {th }} \mathrm{h}$ & 75.9 & 76.6 & 75.2 & 0.40 & 0.625 \\
\hline $4^{\text {th }} \mathrm{h}$ & 80.4 & 81.2 & 81.0 & 0.24 & 0.586 \\
\hline \multicolumn{6}{|c|}{ Acetic acid, \% mol } \\
\hline $0^{\text {th }} \mathrm{h}$ & 59.2 & 60.2 & 61.4 & 0.64 & 0.670 \\
\hline $4^{\text {th }} \mathrm{h}$ & $55.5^{c}$ & $59.3^{b}$ & $63.3^{\mathrm{a}}$ & 2.25 & $<0.001$ \\
\hline \multicolumn{6}{|c|}{ Propionic acid, \% mol } \\
\hline $0^{\text {th }} \mathrm{h}$ & 22.8 & 21.6 & 21.5 & 0.42 & 0.627 \\
\hline $4^{\text {th }} \mathrm{h}$ & $25.3^{a}$ & $21.5^{b}$ & $17.8^{\mathrm{c}}$ & 2.17 & $<0.001$ \\
\hline \multicolumn{6}{|c|}{ Butyric acid, \% mol } \\
\hline $0^{\text {th }} \mathrm{h}$ & $13.3^{\mathrm{a}}$ & $13.2^{\mathrm{a}}$ & $10.9^{b}$ & 1.20 & 0.006 \\
\hline $4^{\text {th } h}$ & $14.3^{\mathrm{a}}$ & $14.0^{\mathrm{a}}$ & $11.9^{b}$ & 0.75 & 0.009 \\
\hline \multicolumn{6}{|c|}{ Valeric acid, $\% \mathrm{~mol}$} \\
\hline $0^{\text {th }} \mathrm{h}$ & $3.4^{b}$ & $3.6^{\mathrm{b}}$ & $4.9^{\mathrm{a}}$ & 0.47 & 0.012 \\
\hline $4^{\text {th }} \mathrm{h}$ & $3.5^{\mathrm{b}}$ & $3.7^{b}$ & $5.1^{\mathrm{a}}$ & 0.50 & 0.010 \\
\hline \multicolumn{6}{|c|}{ Caproic acid, \% mol } \\
\hline $0^{\text {th }} \mathrm{h}$ & 1.3 & 1.4 & 1.3 & 0.03 & 0.682 \\
\hline $4^{\text {th }} \mathrm{h}$ & $1.4^{b}$ & $1.5^{\mathrm{b}}$ & $1.9^{\mathrm{a}}$ & 0.15 & 0.021 \\
\hline \multicolumn{6}{|c|}{ Acetic acid/Propionic acid } \\
\hline $0^{\text {th }} \mathrm{h}$ & 2.59 & 2.79 & 2.85 & 0.079 & 0.664 \\
\hline $4^{\text {th }} \mathrm{h}$ & $2.20^{c}$ & $2.75^{b}$ & $3.55^{\mathrm{a}}$ & 0.392 & $<0.001$ \\
\hline \multicolumn{6}{|c|}{ Ammonia nitrogen, mg/dl } \\
\hline $0^{\text {th }} \mathrm{h}$ & 13.2 & 13.2 & 12.3 & 0.30 & 0.628 \\
\hline $4^{\text {th }} \mathrm{h}$ & $17.5^{\mathrm{a}}$ & $15.7^{\mathrm{b}}$ & $14.3^{c}$ & 0.93 & $<0.001$ \\
\hline
\end{tabular}

Control - DAP treatment without ensiling, DAP - treatment as total mixed ration silage containing dry apple pomace, FAP - treatment as total mixed ration silage containing fresh apple pomace, SEM - standard error of the mean; ${ }^{\text {abc }}$ - values within the same row with different superscripts are significantly different at $P<0.05$

However, at the $4^{\text {th }} \mathrm{h}$ after feeding, the concentration was highest in control, followed by DAP, then FAP treatment $(P<0.05)$.

\section{Discussion}

Fermentation quality of TMRS. In some studies it was shown that FAP is a fermentative material due to its high sugar content (Fang et al., 2016). In the present study, both TMRS with DAP and FAP were well fermented if evaluated by low $\mathrm{pH}$ and high lactic acid, and there were no problems 
with long-term preservation. However, high ethanol production in TMRS causes a high DM loss so the fermentation cannot be regarded as a good quality one. Ethanol is produced in silage containing ingredients such as sweet sorghum (Gallagher et al., 2018), sugar cane (Pedroso et al., 2005) and pineapple (Nisarani et al., 2015), and its production in silage is affected by yeast count (Weiss et al., 2016). In the present study, the DAP was dried for $4 \mathrm{~h}$ at $110{ }^{\circ} \mathrm{C}$, which exceeds the sterilization temperature of $60^{\circ} \mathrm{C}$ for yeast (Arthur and Watson, 1976); therefore, most of the yeast may have died out during the drying process, resulting in significantly lower ethanol production in the DAP TMRS. The lactic acid in silage is mainly produced by lactic acid bacteria using water-soluble carbohydrates, and its production is affected by the activity of lactic acid bacteria (Cai et al., 1999). In the present study, maize, DAP and FAP containing high watersoluble carbohydrates (sugar or starch) were used in high proportions in the TMRS (132.2, 200 and $200 \mathrm{~g} / \mathrm{kg} \mathrm{DM}$, respectively). They provided an adequate substrate for lactic acid fermentation. Predicted from this condition, there should be no difference in lactate acid; still, lactic acid production differed between the FAP and DAP treatments. Because ethanol has an antibacterial effect, its concentration may have affected the lactic acid bacteria activity. Fang et al. (2016) studied the fermentation quality of TMRS containing FAP at different proportions. They found that lactic acid production peaked when the ethanol concentration was less than $20 \mathrm{~g} / \mathrm{kg}$ but decreased significantly at ethanol concentrations above $20 \mathrm{~g} / \mathrm{kg}$. In the present study, the ethanol concentrations in TMRS with FAP and DAP were 36.1 and $8.93 \mathrm{~g} / \mathrm{kg}$, respectively. The higher ethanol in TMRS with FAP may have inhibited lactic acid bacteria activity, resulting in lower lactic acid than in the DAP treatment. The lower acetic acid levels in TMRS with FAP may be also caused by ethanol inhibiting the activity of acetic acid-producing bacteria. The acetic acid in silage is produced by plural course (Limin et al., 2018), and as it was shown in our previous experiment (Fang et al., 2016; 2020), the effect of ethanol concentration on acetic acid production is often variable in TMRS containing FAP. Thus, it was not clear why acetic acid production differed between FAP and DAP treatments in the present study. Regarding the ammonia N, ethanol in TMRS may also affect the activity of proteolytic bacteria, and $\mathrm{Xu}$ et al. (2001) reported that ammonia $\mathrm{N}$ in tofu-cake silage decreased with the ethanol addition.
Thus, the lower ammonia $\mathrm{N}$ observed in TMRS of FAP may have been due to the inhibition of protein degradation by ethanol during fermentation.

Feed intake and digestibility. Some studies have shown that the fermentation products of silage affect feeding preferences and feed intake (Buchanan-Smith, 1990); however, feed intake was not affected by the diet in the present study. The non-roughage proportion of diet was high $(520 \mathrm{~g} / \mathrm{kg})$; maize, wheat bran, soyabean meal, DAP and FAP were willingly eaten by the animals. These materials with high preferences may have exceeded the effect of fermentation on feed intake, so no differences in the intake were found among treatments. It was observed in some studies that lactic or acetic acids in silage can affect digestibility. However, Hino et al. (1992) reported that continuous ethanol ingestion inhibits the growth of rumen microorganisms, while another study showed that ethanol ingestion reduces digestibility for ruminants (Emery et al., 1959). In the present study, the nutrient digestibility significantly decreased in DAP and FAP treatments in comparison to control.

Furthermore, the digestibility of EE, ADF and NDF in FAP significantly decreased in comparison to those in DAP. These results indicate that the decrease in digestibility may have been caused by ethanol ingestion, and the its effects increased with ethanol intake. This result is consistent with previous reports (Fang et al., 2016; 2020). Another difference among treatments was that the DAP was dried at $110{ }^{\circ} \mathrm{C}$ for $4 \mathrm{~h}$. Although a high-temperature drying process can reduce the digestibility of CP (Böttger and Südekum, 2018), no difference in CP digestibility was found between FAP and DAP treatments in this study. Since apple pomace contains very little $\mathrm{CP}$, and most of it is concentrated in seed (Yu et al., 2007), and as shown in our previous study, sheep can barely digest seeds in apple pomace (Fang et al., 2020), no effects of high temperature on CP digestibility were found. Faecal $\mathrm{N}$ was higher in the DAP and FAP treatments, but the intake and urine $\mathrm{N}$ were similar among treatments, leading to lower $\mathrm{N}$ retention. This is consistent with the CP digestibility.

Rumen fermentation. Ethanol produced in TMRS containing FAP increases the molar proportions of acetic, valeric and caproic acids; and decreases the proportion of propionic acid in the rumen fluid of cows, the effects of which increase with ethanol intake (Fang et al., 2016). Similar results were noted when ruminants were fed ethanol (Pradhan and Hemken, 1970; Miyazaki et al., 1991). 
The relationship between rumen fermentation and ethanol ingestion found here is consistent with previous studies, and concerns individual rumen VFA concentrations at the $4^{\text {th }} \mathrm{h}$ after feeding and the ethanol content in the diet. Therefore, VFA in the rumen may also be affected by ethanol. The reason for increasing values of acetic, valeric and caproic acids in FAP and DAP treatments is discussed by Miyazaki et al. (1991). Ethanol in feed, in addition to inhibiting the microorganisms of the rumen, can be also generated to acetyl-CoA, which is then used as an intermediate product to generate acetic, valeric and caproic acids. When the effect of ethanol on inhibiting the microorganisms of the rumen is relatively weak, ethanol in feed increases these acids due to the process described above. Ammonia $\mathrm{N}$ in the rumen is derived from $\mathrm{CP}$ decomposition by microorganisms. The $\mathrm{CP}$ content and composition were almost identical among the treatments, so the difference in ammonia $\mathrm{N}$ may have been caused by fermentation products. Hino et al. (1992) reported that ethanol ingestion inhibits the growth of rumen microorganisms and rumen protein degradation in goats; thus, changes in rumen ammonia $\mathrm{N}$ may be also caused by ethanol ingestion.

Our results indicate that DAP also ferments vigorously and produces ethanol in TMRS. Although the ethanol production was significantly lower in TMRS containing $200 \mathrm{~g} / \mathrm{kg}$ DM of DAP instead of FAP, its concentration still had a negative impact on digestibility and $\mathrm{N}$ retention due to its strong irritant effect. To prevent ethanol negative effects, one should consider the proportion of FAP or DAP in TMRS and employ a means of inhibiting ethanol production when ensiling.

\section{Conclusions}

It was indicated that ethanol is also produced in total mixed ration silage (TMRS) containing dry apple pomace (DAP). Although ethanol has no negative effect on feed preservation, it causes dry matter (DM) loss, so TMRS cannot be evaluated as being a good quality one. At the same proportion of $200 \mathrm{~g} / \mathrm{kg} \mathrm{DM}$, the ethanol content in TMRS with DAP was lower than in TMRS with fresh apple pomace (FAP), but it still decreased digestibility and nitrogen retention, notwithstanding there were potential confunding effects between period and treatment in the feeding trail. If DAP is used to prepare TMRS, its proportion should be reduced. From a practical point of view the ethanol production in TMRS with FAP should be inhibited by reducing proportion, adding yeast inhibitors or water-absorbing materials, etc. Whereas direct use of DAP without ensiling may be a better option in ruminant feeding.

\section{Conflict of interest}

The Authors declare that there is no conflict of interest.

\section{References}

AOAC (Association of Official Analytical Chemists), 1990. Official Methods of Analysis of the Association of Official Analytical Chemists. $15^{\text {th }}$ Edition. Arlington, VA (USA)

Arthur H., Watson H., 1976. Thermal adaptation in yeast: growth temperatures, membrane lipid, and cytochrome composition of psychrophilic, mesophilic, and thermophilic yeasts. J. Bacteriol. 128, 56-68, https://doi.org/10.1128/JB.128.1.5668.1976

Barker S.B., Summerson W.H., 1941. The colorimetric determination of lactic acid in biological material. J. Biol. Chem. 138, 535-554, https://doi.org/10.1016/S0021-9258(18)51379-X

Böttger C., Südekum K.H., 2018. Review: protein value of distillers dried grains with solubles (DDGS) in animal nutrition as affected by the ethanol production process. Anim. Feed Sci. Technol. 244, 11-17, https://doi.org/10.1016/j.anifeedsci.2018.07.018

Buchanan-Smith J.G., 1990. An investigation into palatability as a factor responsible for reduced intake of silage by sheep. Anim. Sci. 50, 253-260, https://doi.org/10.1017/S0003356100004700

Cai Y., Benno Y., Ogawa M., Kumai S., 1999. Effect of applying lactic acid bacteria isolated from forage crops on fermentation characteristics and aerobic deterioration of silage. J. Dairy Sci. $\quad 82, \quad 520-526$, https://doi.org/10.3168/jds.S00220302(99)75263-X

Dewar W.A., McDonald P., 1961. Determination of dry matter in silage by distillation with toluene. J. Sci. Food. Agric. 12, 790-795, https://doi.org/10.1002/jsfa.2740121112

Emery R.S., Lewis T.R., Everett J.P., Lassiter C.A., 1959. Effect of ethanol on rumen fermentation. J. Dairy Sci. 42, 1182-1186, https://doi.org/10.3168/jds.S0022-0302(59)90710-6

Fang J., Cao Y., Matsuzaki M., Suzuki H., 2016. Effects of apple pomace proportion levels on the fermentation quality of total mixed ration silage and its digestibility, preference and ruminal fermentation in beef cows. Anim. Sci. J. 87, 217-223, https://doi.org/10.1111/asj.12410

Fang J., Xia G., Cao Y., 2020. Effects of replacing commercial material with apple pomace on the fermentation quality of total mixed ration silage and its digestibility, nitrogen balance and rumen fermentation in wethers. Grass. Sci. 66, 124-131, https://doi. org/10.1111/grs.12258

Gallagher D., Parkera D., Allena D.J., Tsesmetzisa N., 2018. Dynamic bacterial and fungal microbiomes during sweet sorghum ensiling impact bioethanol production. Biores. Technol. 264, 163-173, https://doi.org/10.1016/j.biortech.2018.05.053

Gasa J., Castrillo C., Guada J.A., Balcells J., 1992. Rumen digestion of ensiled apple pomace in sheep: effect of proportion in diet and source of nitrogen supplement. Anim. Feed Sci. Technol. 39, 193-207, https://doi.org/10.1016/0377-8401(92)90041-4

Hino T., Miyazaki K., Kuroda S., Gotoh T., 1992. Effect of ethanol on the degradation of protein and amino acids by rumen microorganisms (in Japanese). Anim. Sci. Technol. (Jpn.) 63, 173-179, https://doi.org/10.2508/chikusan.63.173 
Limin K.Jr., Shaver R.D., Grant R.J., Schmidt R.J., 2018. Silage review: Interpretation of chemical, microbial, and organoleptic components of silages. J. Dairy Sci. 101, 4020-4033, https:// doi.org/10.3168/jds.2017-13909

Magyar M., Sousa L.C., Jin M., Sarks C., Balan V., 2016. Conversion of apple pomace waste to ethanol at industrial relevant conditions. Appl. Microbiol. Biotechnol. 100, 7349-7358, https://doi.org/10.1007/s00253-016-7665-7

Miyazaki K., Hino T., Itabashi H., 1991. Possible factor altering volatile fatty acid production in the ethanol-fed rumen (in Japanese). Anim. Sci. Technol. (Jpn.) 62, 1000-1005, https://doi. org/10.2508/chikusan.62.1000

Nisarani K.S.G., Naglapura C.V., Vaibhav B.A., Samireddypalli A., Din T.P., Cadaba S.P., 2015. Study on evaluation of silage from pineapple (Ananas comosus) fruit residue as livestock feed. Trop. Anim. Health Prod. 47, 557-561, https://doi. org/10.1007/s11250-015-0762-2

Pedroso A.F., Nussio L.G., Paziani S.F., Loures D.R.S., Igarasi M.S., Coelho R.M., Packer I.H., Horii J., Gomes L.H., 2005. Fermentation and epiphytic microflora dynamics in sugar cane silage. Sci. Agric. 62, 427-432, https://doi.org/10.1590/ S0103-90162005000500003

Perussello C.A., Zhang Z., Marzocchella A., Tiwari B.K., 2017. Valorization of apple pomace by extraction of valuable compounds. Compr. Rev. Food Sci. Food Saf. 16, 776-796, https://doi.org/10.1111/1541-4337.12290

Pradhan K., Hemken R.W., 1970. Utilization of ethanol and its effect on fatty acid patterns in ruminants. J. Dairy Sci. $53,1739-1746$, https://doi.org/10.3168/jds.S0022-0302(70)86472-4
Randby Å.T., Selmer-Olsen I., Bavere L., 1999. Effect of ethanol in feed on milk flavor and chemical composition. J. Dairy Sci. 82, 420-428, https://doi.org/10.3168/jds.S00220302(99)75248-3

Shalini R., Gupta D.K., 2010. Utilization of pomace from apple processing industries: a review. J. Food Sci. Technol. 47, 365-371, https://doi.org/10.1007/s13197-010-0061-x

Van Soest P.J., Robertson J.B., Lewis B.A., 1991. Methods for dietary fiber, neutral detergent fiber, and non-starch polysaccharides in relation to animal nutrition. J. Dairy Sci. 74, 3583-3597, https://doi.org/10.3168/jds.S0022-0302(91)78551-2

Weiss K., Kroschewski B., Auerbach H., 2016. Effects of air exposure, temperature and additives on fermentation characteristics, yeast count, aerobic stability and volatile organic compounds in corn silage. J. Dairy Sci. 99, 8053-8069, https://doi. org/10.3168/jds.2015-10323

Xu C., Suzuki H., Toyokawa K., 2001. Characteristics of ruminal fermentation of sheep fed tofu cake silage with ethanol. Jap. Anim. Sci. J. 72, 299-305, https://doi.org/10.2508/ chikusan.72.299

Xu C., Cai Y., Fukasawa M., Matsuyama H., Moriya N., 2008. The effect of replacing brewers' grains with barley tea grounds in total mixed ration silage on feed intake, digestibility and ruminal fermentation in wethers. Anim Sci. J. 79, 575-581, https://doi.org/10.1111/j.1740-0929.2008.00566.x

Yu X., van de Voort F.R., Li Z., Yue T., 2007. Proximate composition of the apple seed and characterization of its oil. Int. J. Food Engine. 3, 12, https://doi.org/10.2202/1556-3758.1283 